\title{
重度障害児の排泄実態と排泄環境整備
ACTUAL SITUATION OF EXCRETION AMONG SEVERELY DISABLED CHILDREN AND THE DEVELOPMENT OF BETTER EXCRETION ENVIRONMENTS

\author{
植田瑞昌 ${ }^{* 1}$, 八藤後 猛 ${ }^{* 2}$ \\ Mizuyo UEDA and Takeshi YATOGO
}

\begin{abstract}
The actual situations of the way severely disabled children excrete and excretory environment are unclear. The objective of our studies is to highlight how to develop excretion environments that are appropriate for the stages of growth of severely disabled children. The survey was conducted through a questionnaire and severely disabled children were classified into five groups based on their physical functions or excretion conditions. As a result, A number of children would be able to excrete at toilets if the environments were appropriate. Children can hardly use public toilets away from home.
\end{abstract}

Keywords: Disabled children, Excretory environment, Toilet, Diapers, Excretion disability,

障害児，排泄環境，トイレ，おむつ，排泄障害

\section{1. 研究の背景と目的}

近年, 在宅生活を送る障害児を取り巻く支援環境は大きく変化し ている.18歳未満の障害児に対して, 以前は児童福祉法と障害者総 合支援法に基づき支援及びサービスの提供が実施されてきたが, 2012 (平成24) 年から児童福祉法に一元化された．同時に，児童発達 支援センターは，より身近な地域で障害児の支援及び早期発見・早 期療育を提供できるようになった。また，同年，文部科学省は，障 害のある子と障害のない子が地域で共に学ぶ仕組みづくり, 及び障 害のある子の状況に応じて必要な教育環境を整備する「インクルー シブ教育システム構築」に向け事業を開始した.

このような社会変化の影響を受け, 在宅生活を送る医療的ケア注 1) を必要とする障害児が増加 ${ }^{1)}$ し, 重度障害児への行政施策を推進 しようとする気運が高まっている注2)。しかし，いまだ日常生活の ほとんどの介助を母親が担っているが2）その負担は大きい。中で も一日数回必要となる排泄介助はとくに負担が大きい.

障害児が排泄動作を獲得するまでには，尿意・便意の感覚，排泄 の告知と意思伝達能力, 移乗 - 移動能力, 姿勢保持能力などさまざ まな要素が加わり, 医学, 療育, 福祉, 教育の連携が欠かせない. ところが, 現行では病院や療育施設・特別支援学校などで排泄指導 や訓練を行っているが，在宅での生活環境まで配慮されていない. また，一般的に自宅や公共施設のトイレは成人に合わせて設計さ れ，療育施設や特別支援学校は，障害児の成長・発達に合わせた排 泄環境は必ずしも十分ではない

そこで, 本研究は, さまざまな障害児の心身状況及びおむつ使用
等の排泄状況を明らかにし，障害別・排泄場所 (自宅，通園・通学 先, 外出先) 別にみた排泄環境整備の実態を明らかにすることを目 的とする.

\section{2. 既往研究と本研究の位置づけ}

障害児の排泄に関連する研究は, 医学, 理学療法, 作業療法分野 で「排泄ケア」に関する文献に散見されるが，おむつの当て方，導 尿指導，姿勢保持方法にとどまり，在宅における生活環境に言及し た文献は見当たらない。西村 ${ }^{3)}$ は在宅での排泄ケアについて対象 となる障害別に細かく記述しているが成人の障害者や高齢者に関す る内容である．重症心身障害児やさまざまな障害児に関する研究な らびに情報はない.

療育及び介護分野では，障害児に対応した排泄指導に関する文献 が見られる. 江草ら ${ }^{4)}$ は重症心身障害児の排泄指導の方法及びお むつ・トイレ介助での配慮点を示している.しかし, 住環境や用具 等には言及していない, また, 中村ら ${ }^{5)}$ は重症心身障害児の排泄 指導について用具等を紹介しているが，排泄に関する働きかけをし ても障害児からの反応が乏しいと，おむつ交換やトイレ介助にとど まり，快・不快の感覚や子どもの育ちを学ぶ「排泄教育」注3)が行 われない場合があるとし，その原因に「排泄指導を行うためのトイ レ施設・設備など物的環境が整えられていない」障害ゆえにできな いものなのか，本当はできるのに育てられてこなかったためにでき なくなっているものなのか区別する必要がある」と指摘している.

一方, 建築学分野では, 高齢者及び障害者の排泄環境に関して入

\footnotetext{
*1 日本大学大学院理工学研究科博士後期課程建築学専攻 修士 (工学)

*2 日本大学理工学部まちづくり工学科 教授・博士 (工学

Grad. Student, Graduate School of Sience and Technology, Nihon University, M.Eng.

Prof., Dept. of Town Planning and Design, CST, Nihon University, Dr.Eng.
} 
所施設や病棟内，公共トイレに関する論文は多数あるが，在宅に関 しては少ない. 野村 ${ }^{6)}$ は高齢者や障害者の排泄のための住環境整 備について報告を行っているが，18歳未満の障害児の排泄環境には 言及していない。唯一, 野口ら ${ }^{7)}$ が障害児の住環境整備に関連し て，トイレや排泄介助の困りごとを報告している.

そこで, 本研究は, 明らかにされていない障害児の障害別・排泄 場所別の排泄実態を把握し, 建築計画における障害児の排泄環境整 備の基礎的研究として位置づける.

\section{3. 研究方法}

本研究では，まず障害児 (以下「児」とする)の身体機能及び排泄 実態を把握し, 現段階での問題点を明らかにする. 次に, 障害の程 度や排泄実態等を考察し, 坚をグループ化する. さらに，グループ 別に使用する設備及び用具類等排泄環境に関する分析を行う.

調查手法には, 览の排泄状況には個別性が高く, 個別調查のみで は全体像を把握することができないこと，また，各年代ごとに多く の児の排泄実態を把握することが必要なことから, アンケート調査 を採用した。

\section{（1） アンケート調査の配布方法と配布先}

アンケートは，特別支援学校・览童発達支援センター及び首都 圈, 某県の父母の会・親の会, 自主サークル等を通じて保護者へ配 布し, 郵送により回収した. なお, アンケートは18歳未満の「障害 のある子ども」のいる保護者への配布を依頼したが，依頼団体に よって児の年齢確認が困難な場合は, 全会員（家庭）へ配布した. 倫理的配慮として，アンケートへの回答は，任意かつ無記名を原則 注4) とし，回答用紙の返信をもって同意したものとした.

$\begin{array}{ll}\text { 配布期間 } & : 2016 \text { 年 } 5 \text { 月 8 月 } \\ \text { 配布数 } & : 2378 \text { 部 (回答者数 } 729 \text { 人) } \\ \text { 回収率 } & : 30.7 \%\end{array}$

\section{（2）アンケート調査の内容}

アンケートの内容は,「児の基本属性」「排泄状況」「排泄環境」「介 助者の状況・その他」の 4 部門からなる. 詳細は以下に記す.

i ) 児の基本属性 身長・体重, 年齢 - 性別, 主障害, 手帳の有無 と等級, 姿勢保持状況, 意思伝達方法, 外出先と外出頻度, 医療 的ケアの有無, 等

ii ) 排泄状況 排泄障害注5) の有無, おむつの使用状況, 排泄回数 時間，便意・尿意の告知，排泄動作の自立度，等

iii) 排泄環境 排泄姿勢 ・場所, 排泄場所までの移動方法, 排泄時 に使用する設備・用具類，等

iv) 介助者の状況 - その他 介助者の年齢 - 性別, 排泄に関する環 境整備の有無と内容, トイレでの排泄希望, 排泄環境に関する困 りごとの自由回答，等

\section{4. アンケート調査結果}

障害者を対象とした研究では, 対象者を法体系に準拠し「身体障 害」と「知的障害」に分類して集計・分析することが基本であり，さ らに身体障害と知的障害が重複している場合は「重複障害」と称し, これを障害の一分類として捉え, 計 3 分類で集計・分析することが 多い. 本研究でもこれに準拠して, 身体障害 (以下〈身体〉と略 す), 知的障害注 6) (以下 〈知的・発達〉 と略す), 重複障害注 7) (以下
〈重複〉と略す)の 3 障害で分析する注8).

集計の結果，回答者 729 人中 18 歳未満の览は 617 人であり，障害 別にみると〈重複〉が 294 人，〈身体〉が59人，〈知的・発達〉が 259 人, 及び障害種別が不明の児が 5 人であったため，不明を除く 612 人を以降の分析対象とする.

\section{1 児の基本属性}

\section{（1）性別と年齢}

男女比は 3 障害とも男児が多く，〈重複〉では男児 177 人，女児 116 人，不明 1 人，〈身体〉では男児 31 人，女児 28 人，〈知的・発 達〉では男児 199 人，女児 60 人である。また 3 歳以下を除き，4歳 から17歳の各年齢における回収人数はほぼ等しい数である.

\section{（2）手帳の所持状況と等級 Table 1}

障害関係の手帳を所持している児は，〈重複〉では290人

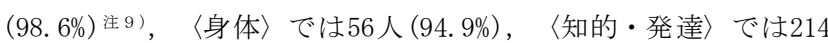
人 $(82.6 \%)$ であり，ほとんどの览が何らかの手帳を所持している.

〈重複〉では身体障害者手帳と療育手帳の両方を所持し，かつ 手帳の等級がわかる児は，185人 (62.9\%)注9)である。また，身体障 害者手帳 1 級及び 2 級かつ療育手帳 1 度注10) 及び 2 度である児が 140 人 $(47.6 \%)$ と最も多い。〈身体〉では身体障害者手帳 1 級及び 2 級である児が 51 人 $(86.4 \%)$ と最も多い。〈知的・発達〉では療育 手帳 1 度及び 2 度 (最重度) は 88 人 (34.0\%) である。なお, 精神障害 者保健福祉手帳を有する児は〈重複〉に 2 名, 〈知的・発達〉に 3 名含まれるが，少数であったため，本項では「身体障害者手帳」と 「療育手帳」の等級のみを示す。

\section{（3）医療的ヶアの有無と内容}

医療的ケアが必要な児の割合は，〈重複〉では121人 (41.2\%), 〈身体〉では 17 人 $(28.8 \%)$ である。医療的ケアの内容は，「痰の吸 引」が最も多く, 〈重複〉では 77 人 $(26.2 \%),\langle$ 身体〉では 12 人 (20.3\%)である.また，「導尿」「人膀胱・肛門」「尿道留置カテー

Table 1 Certificate and grade possessed by disabled children (Unit:people)

\begin{tabular}{|c|c|c|c|c|c|c|}
\hline \multirow{3}{*}{\multicolumn{2}{|c|}{$\begin{array}{c}\langle\text { Multiple }\rangle \\
\mathrm{N}=185\end{array}$}} & \multicolumn{4}{|c|}{ Rehabilitation notebook } & \multirow{3}{*}{$\begin{array}{c}\langle\text { Physical } \\
N=53\end{array}$} \\
\hline & & \multicolumn{2}{|c|}{$\mathrm{A}$} & \multicolumn{2}{|c|}{$\mathrm{B}$} & \\
\hline & & $\begin{array}{l}\text { Level } 1 \\
\text { (A1) }\end{array}$ & $\begin{array}{l}\text { Level } 2 \\
\text { (A2) }\end{array}$ & $\begin{array}{c}\text { Level } 3 \\
\text { (B1) }\end{array}$ & \begin{tabular}{|c|} 
Level 4 \\
$(\mathrm{~B} 2)$
\end{tabular} & \\
\hline physically & Grade 1-2 & \multicolumn{2}{|c|}{140} & \multicolumn{2}{|c|}{17} & 51 \\
\hline certificate & Grade 3-6 & \multicolumn{2}{|c|}{22} & \multicolumn{2}{|c|}{6} & 2 \\
\hline \multicolumn{2}{|c|}{$\langle$ 〈Intellectual〉N=205 } & \multicolumn{2}{|c|}{88} & \multicolumn{2}{|c|}{117} & \\
\hline
\end{tabular}

Table 2 Ability to maintain position for each disabled child (Unit:people, Blank=0)

\begin{tabular}{|c|c|c|c|c|}
\hline \multicolumn{2}{|c|}{$\begin{array}{ll}\text { Position } & \text { Disability } \\
\end{array}$} & $<$ Multiple $>$ & $<$ Physical $>$ & $<$ Intellectual $>$ \\
\hline \multirow{4}{*}{$\begin{array}{c}\mathrm{i} \\
\text { Standing } \\
\text { position }\end{array}$} & Possible & $78(26.6 \%)$ & $15(25.4 \%)$ & $255(98.8 \%)$ \\
\hline & Partially possible & $66 \quad(22.5 \%)$ & $16(27.1 \%)$ & $3 \quad(1.2 \%)$ \\
\hline & Impossible & $149(50.9 \%)$ & $28(47.5 \%)$ & \\
\hline & Total & $293(100 \%)$ & $59(100 \%)$ & $258(100 \%)$ \\
\hline \multirow{4}{*}{$\begin{array}{c}\text { ii } \\
\text { Sitting } \\
\text { position }\end{array}$} & Possible & $153(52.2 \%)$ & $29(49.2 \%)$ & $256(99.6 \%)$ \\
\hline & Partially possib & $51(17.4 \%)$ & $10(16$. & $1 \quad(0.4 \%)$ \\
\hline & Impossible & $89(30.4 \%)$ & $20(33.9 \%)$ & \\
\hline & Total & $293(100 \%)$ & $59(100 \%)$ & $257(100 \%)$ \\
\hline \multirow{4}{*}{$\begin{array}{c}\text { iii } \\
\text { Rolling } \\
\text { over }\end{array}$} & Possible & $197(67.5 \%)$ & $\begin{array}{ll}41 \quad(69.5 \%) \\
\end{array}$ & $257(100 \%)$ \\
\hline & Partially possible & $24 \quad(8.2 \%)$ & $7 \quad(11.9 \%)$ & \\
\hline & Impossible & $71 \quad(24.3 \%)$ & $11(18.6 \%)$ & \\
\hline & Total & $292(100 \%)$ & $59(100 \%)$ & $257(100 \%)$ \\
\hline \multirow{3}{*}{$\begin{array}{l}\text { iv } \\
\text { Neck } \\
\text { control }\end{array}$} & Possible & $214(73.8 \%)$ & $43(74.1 \%)$ & $257(100 \%)$ \\
\hline & Impossible & $76 \quad(26.2 \%)$ & $15(25.9 \%)$ & \\
\hline & Total & $290(100 \%)$ & $58 \quad(100 \%)$ & $257(100 \%)$ \\
\hline
\end{tabular}


テル」注11)の 3 項目は，〈重複〉では16人 (5.4\%)，〈身体〉では 2 人 (3.4\%) とわずかであり，〈知的・発達〉では皆無である.

\section{（4）姿勢保持能力}

生活動作の最も基本となる「立つ」「座る」「寝返り」の姿勢保持能 力を「できる」「支えがあれば(少し手伝えば)できる」「できない」の 3 段階, 「首の寸わり」の姿勢保持能力を「すわっている」「すわってい ない」の 2 段階に区分し，その状況をTable 2 に示寸.

i ) 立位 立位が「できる」児は, 〈重複〉及び〈身体〉では少なく, 半数近く は「できない児である.〈知的・発達〉では255人(98.8\%)とほぼ全員が 立位ができる.

ii ）座位 座位が「できる」児は, 〈重複〉では 153 人(52.2\%),〈身体〉では 29人(49.2\%)である.〈知的・発達〉では256人(99.6\%)とほぼ全員が座位 ができる.

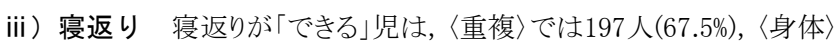
では41人(69.5\%)である.〈知的・発達〉では全員寝返りができる.

iv ）首のすわり 首が「すわっている」児は,〈重複〉では214人(73.8\%), 〈身体〉では 43 人 $(74.1 \%)$ である.〈知的・発達〉では全員の首がすわっ ている.

\section{（5）日常生活における意思伝達方法}

排泄を介助者に告知するには児の意思表示が必要となる．そこ で, 日常生活における児の意思表示の方法を「口話・ことば」「身ぶ り・指さし・サイン」注12)「表情から読夕取る」「意思表示はわからな いに区分し，どのような方法を行っているかを障害別にFig. 1 に 示す。〈重複〉では本人の意思表示はないが介助者が「表情から読 み取る」児が 137 人 (46.8\%) と最も多い。〈身体〉及び〈知的・発 達〉では「口話・ことば」で意思表示をする児がそれぞれ 38 人 (64. 4\%)，184人 (71.9\%) と最も多い.

\section{（6）児の姿勢·感覚・行動等}

児が排泄動作を行いやすくするためには，排泄時の姿勢，身体の 動き・動作もしくは感覚等への配慮が必要と考える. そこで, 児の 心身状態の把握を行いFig. 2 に示す.

i ) 姿勢等 〈重複〉では「側わん」注13)のある览が 115 人 (40.1\%) と最 も多い。〈身体〉では「側わん」と強い緊張・拘縮」のある児が

$\square$ Speaking $\square$ Gestures and signs $\square$ Facial expressions $\quad$ Impossible

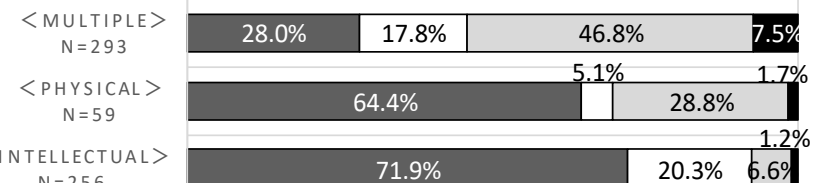

Fig. 1 Communication method $\mathrm{p}=0.000 \%$

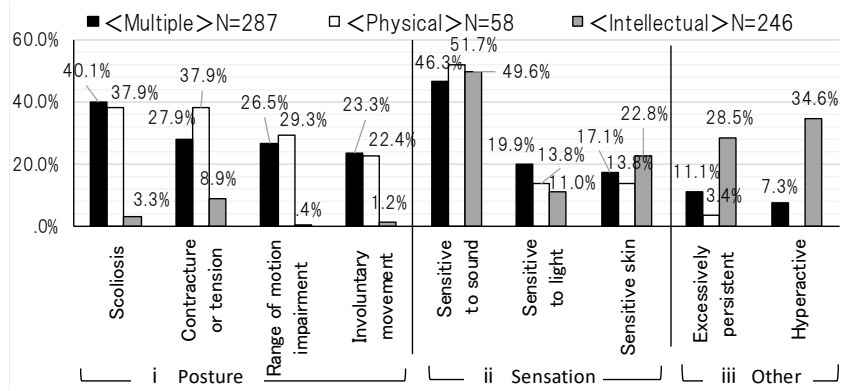

Fig. 2 State of posture, sensation and motion (Multiple answer)
それぞれ 22 人 $(37.9 \%)$ と同数である.

ii ) 感覚 3 障害とも「音に敏感」な巟が最も多く, 〈重複〉では133 人 $(46.3 \%),\langle$ 身体〉では30人 $(51.7 \%),\langle$ 知的・発達〉では 122 人 $(49.6 \%)$ である.

iii）その他の行動特性〈知的・発達〉では「多動」である児が 85 人 (34. 6\%) と最も多い.

\section{2 児の排泄の状況}

重度障害児においては，おむつ使用が必須であったり，おむつの 使用期間が長引くことが多い，そこで，児のおむつ使用状況と排泄 告知の状況を把握する.

\section{（1） おむつ使用率とおむつ離れの年齢}

おむつを使用している児は，〈重複〉では2 64 人 $(89.8 \%) ， 〈$ 身 体〉では 38 人 $(64.4 \%)$, 〈知的・発達〉では 97 人 $(37.5 \%)$ である. 各年齢におけるおむつ使用率をプロットし，指数近似曲線を重ねた 結果をFig. 3 に示す.〈重複〉では 5 歳を過ぎるころからおむつ使 用率が下がり，17歳で $65 \%$ 以下となる。〈身体〉では 3 歳を過ぎる ころからおむつ使用率が下がり 13歳を過ぎるとおむつ使用率は $50 \%$ 以下になる。〈知的・発達〉では 3 歳を過ぎるころに急激におむつ 使用率が下がり 8 歳を過ぎると $40 \%$ 以下になる.

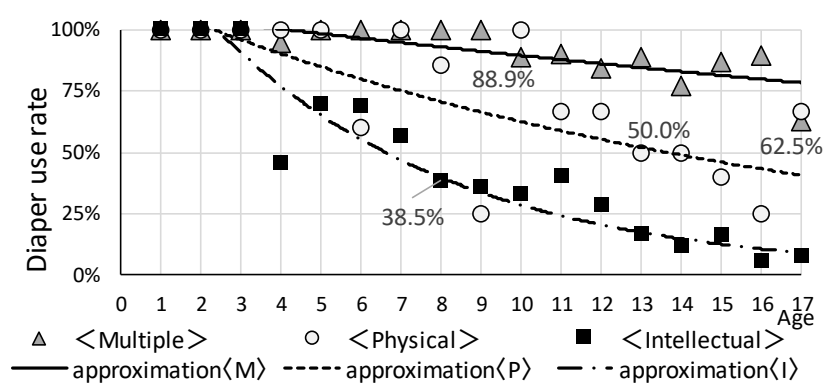

Fig. 3 Diaper use rate by age

$*\langle$ Multiple $\rangle=\langle\mathrm{M}\rangle,\langle$ Physical $\rangle=\langle\mathrm{P}\rangle,\langle$ Intellectual $\rangle=\langle\mathrm{I}\rangle$

$\langle\text { Multiple }\rangle_{\mathrm{p}}=0.001 \%$ $\left\langle\right.$ Physical $\mathrm{p}_{\mathrm{p}}=0.384\langle$ Intellectual $\rangle \mathrm{p}=0.000 \%$

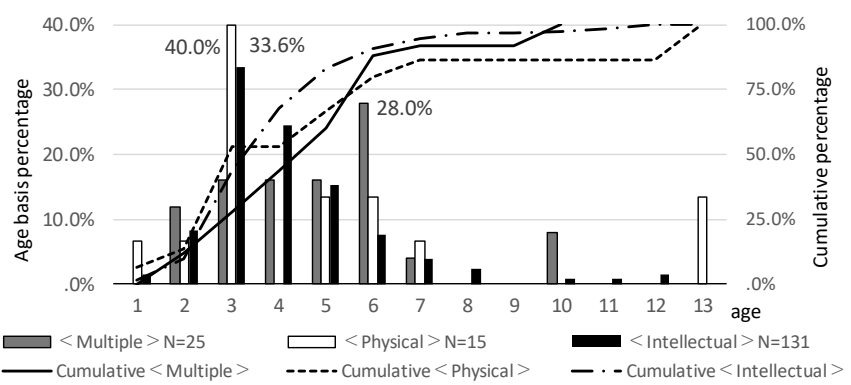

Fig. 4 Percentage and cumulative percentage by age of those who no longer wear diapers $p=0.001 \%$

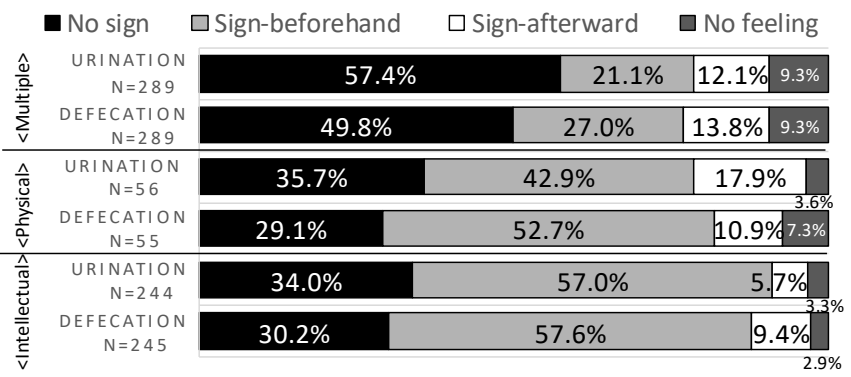

Fig. 5 Being informed by disabled children of urination and defecation. (Urination and Defecation $\mathrm{p}=0.000 \%$ ) 
さらに，現在はおむつを使用していない児のおむつ離れをした時 の年齢別割合と累積割合を重ねた結果をFig. 4 に示す. 〈重複〉で は 6 歳でおむつ離れした児が最も多く, 〈身体〉と〈知的・発達〉 では3歳でおむつ離れをした児が最も多い，3障害ともに，おむつ 離れをした児の $75 \%$ 以上が 7 歳までにおむつ離れをしている.

\section{(2) 排泄告知の状況}

排泄告知の状況を尿意・便意別に，「知らせない「「ととど事前 に知らせる」「ほとんど事後に知らせる」「わからない」４段階とし Fig. 5 に示寸.〈重複〉では，尿意・便意ともに「知らせない」児 の割合が最も高く, 〈身体〉及び〈知的・発達〉では「ほとんど事 前に知らせる」児の割合が高くなる．また， 3 障害ともに尿意より も便意のほうが事前に知らせる児の割合が高くなる.

\section{（3）排泄場所までの移動方法}

日中の居場所から排泄場所までの移動方法をTable 3 注14) に示 す．なお，排尿と排便では同様の傾向を示しているため，排尿時の 移動方法を示す。〈重複〉では, 排泄場所まで移動しない児は自宅 では53人 ( $18.2 \%)$ であり, 通園・通学先では $21 人(7.4 \%)$ に減少 する，移動方法は，自宅は「抱きかかえ・だっこ」で移動する览が 123 人 ( $42.3 \%)$ と最も多いが, 通園・通学先は「手動用車い寸 (介助 者が操作)」を使用する児が 73 人 $(25.6 \%)$ と最も多くなる。〈身体〉 も同様の傾向を示し, 自宅ではあまり福祉用具の利用がなく, 通 園・通学先になると移動方法が変化し, 使用する車いすの種類が増 えている。一方, 〈知的・発達〉では自宅, 通園・通学先ともに排 泄場所までの移動方法は, ほとんどが「歩行」で移動方法に大きな変 化はない.

\section{3 まとめ}

児の基本的な身体機能は，〈重複〉及び〈身体〉では重度障害児 が多く, トイレでの排泄動作に必要な姿勢保持能力は, 〈重複〉及 び〈身体〉ともに同様の傾向を示している。一方，〈知的・発達〉 では身体機能・行動特性等の面で，〈重複〉及び〈身体〉とは異な る傾向を示している，尿意・便意の伝達は，〈重複〉では「知らせ ない」児の割合が高く，〈身体〉及び〈知的・発達〉では「ほとん ど事前に知らせる」児の割合が高い.ささら，排泄場所までの移動 方法は，〈重複〉及び〈身体〉では「自宅」では抱きかかえが多い が「通園・通学先」で用具類を使用する览が増える，おむつ使用率 は〈重複〉及び〈身体〉が全体的に高い。しかし，成長とともにお むつ使用率は下がり，環境により使用する用具類が異なってくるこ

Table 3 How to move to the excretion place (Urination) $※$ Rehabilitation facilities or Schools $=$ Schools (Multiple answer) $($ Blank $=0)$

\begin{tabular}{|c|c|c|c|c|c|c|c|}
\hline \multirow{2}{*}{\multicolumn{2}{|c|}{ Moving method Disability }} & \multicolumn{2}{|c|}{$\langle$ Multiple $\rangle$} & \multicolumn{2}{|c|}{$\langle$ Physical $\rangle$} & \multicolumn{2}{|c|}{$\langle$ 〈Intellectual $\rangle$} \\
\hline & & \multirow{2}{*}{$\begin{array}{l}\text { Home } \\
18.2 \%\end{array}$} & \multirow{2}{*}{\begin{tabular}{|c|}
$\begin{array}{c}※ \\
\text { Schools }\end{array}$ \\
$7.4 \%$ \\
\end{tabular}} & \multirow{2}{*}{$\begin{array}{l}\text { Home } \\
18.2 \%\end{array}$} & \multirow{2}{*}{\begin{tabular}{rl|}
$\begin{array}{c}※ \\
\text { Schools }\end{array}$ \\
$5.7 \%$ \\
\end{tabular}} & \multirow{2}{*}{$\begin{array}{l}\text { Home } \\
1.6 \%\end{array}$} & \multirow{2}{*}{$\begin{aligned} \begin{array}{c}\text { ※ } \\
\text { Schools }\end{array} \\
.8 \%\end{aligned}$} \\
\hline & Same Place & & & & & & \\
\hline \multirow{5}{*}{ 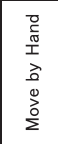 } & walking without assistance & $23.0 \%$ & $20.0 \%$ & $25.5 \%$ & $18.9 \%$ & $95.6 \%$ & $96.8 \%$ \\
\hline & walking with technical aids & & $1.1 \%$ & $1.8 \%$ & $3.8 \%$ & & \\
\hline & Walking with some assistance & $5.2 \%$ & $7.0 \%$ & 7. $3 \%$ & 3. $8 \%$ & 1. $2 \%$ & 1. $2 \%$ \\
\hline & crawling & $11.0 \%$ & $3.2 \%$ & $12.7 \%$ & & $.4 \%$ & \\
\hline & Move with Holding & 42. $3 \%$ & $25.3 \%$ & $32.7 \%$ & $20.8 \%$ & $1.2 \%$ & $.8 \%$ \\
\hline \multirow{5}{*}{ 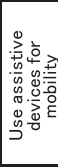 } & wheelchairs(self) & & $6.0 \%$ & & $17.0 \%$ & & \\
\hline & wheelchairs(Assistance) & $1.4 \%$ & $25.6 \%$ & $1.8 \%$ & $24.5 \%$ & & \\
\hline & $\begin{array}{l}\begin{array}{l}\text { Electric-motor-driven } \\
\text { wheelchairs }\end{array} \\
\end{array}$ & & 1. $4 \%$ & $1.8 \%$ & $3.8 \%$ & & \\
\hline & Sitting furnitures with wheels & $1.0 \%$ & 4. $2 \%$ & $5.5 \%$ & $3.8 \%$ & & \\
\hline & Prams/Push-chairs & & $3.9 \%$ & & $5.7 \%$ & & \\
\hline \multirow{2}{*}{\multicolumn{2}{|c|}{$\begin{array}{c}\text { Other } \\
\text { Number of respondents(unitpeople) }\end{array}$}} & $1.0 \%$ & $4 \%$ & & & & $4 \%$ \\
\hline & & 291 & 285 & 55 & 53 & 252 & 248 \\
\hline
\end{tabular}

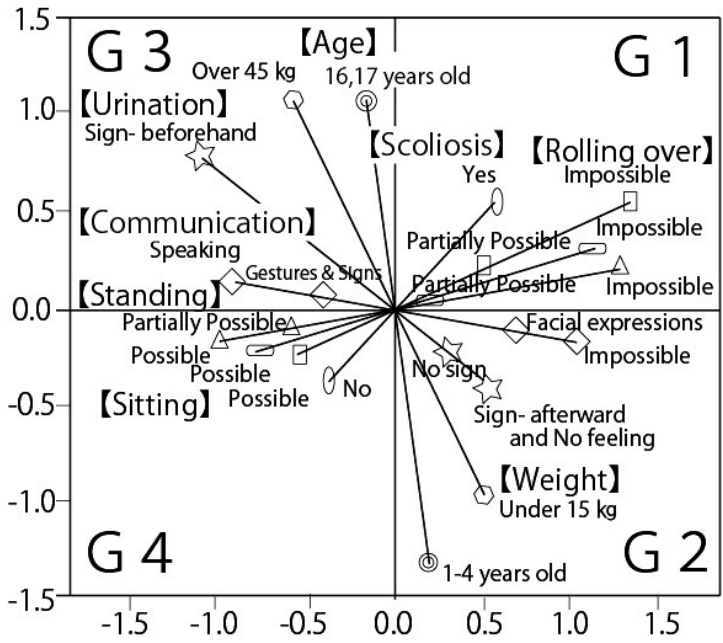

Fig. 6 Bonding plot diagram of categorical points

Table 4 Features of each group

\begin{tabular}{|c|c|c|c|}
\hline 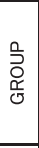 & Features & \begin{tabular}{|} 
ON:Average \\
height \\
UNDER:Average \\
weight \\
(Smallest- \\
Largest) \\
\end{tabular} & $\begin{array}{c}\text { ON:Average } \\
\text { age } \\
\text { (Smallest- } \\
\text { Largest) } \\
\text { UNDER:gende } \\
\text { r ratio } \\
\end{array}$ \\
\hline G1 & $\begin{array}{l}\text { [Sitting position Impossible 80\%】【Neck control Possible 50\%】 } \\
\text { [Communication method Facial expressions70\%】[Need } \\
\text { medical care80\%】【scoliosis:Many】IInform of excretion } \\
\text { NoSign70\%】[Excretion disability60\%】 }\end{array}$ & $\begin{array}{l}132.5 \mathrm{~cm} \\
\left(73^{-161)}\right. \\
24.0 \mathrm{~kg} \\
\left(8.5^{-5}-3\right)\end{array}$ & $\begin{array}{l}\text { 13.1years old } \\
\quad(7-17) \\
\text { Boy: Girl }=1: 1\end{array}$ \\
\hline G2 & $\begin{array}{l}\text { 【Sitting position Impossible50\%】【Neck control Possible50\%】 } \\
\text { 【Communication method Facial expressions70\%】【Need } \\
\text { medical care80\%】【scoliosis: Many】【Inform of excretion No } \\
\text { Sign60\%】【Excretion disability50\%】 }\end{array}$ & $\begin{array}{l}99.3 \mathrm{~cm} \\
\left(62^{-130)}\right. \\
13.1 \mathrm{~kg} \\
\left(6^{-} 23\right) \\
\end{array}$ & $\begin{array}{c}\text { 6.0years old } \\
(1-15) \\
\text { Boy:Girl }=3: 2\end{array}$ \\
\hline G3 & $\begin{array}{l}\text { 【Sitting position Impossible80\%】【Neck control Possible90\%】 } \\
\text { [Communication method Speeking】(Need medical care10\%】 } \\
\text { 【Informed of excretio Sing-beforehand70\%【【Excretion } \\
\text { disability30\%】 }\end{array}$ & $\begin{array}{c}142.3 \mathrm{~cm} \\
\left(105^{-175)}\right. \\
37.0 \mathrm{~kg} \\
\left(12^{-74}\right)\end{array}$ & $\begin{array}{c}\text { 13.3years old } \\
\left(6^{-1} 17\right) \\
\text { Boy: Girl }=3: 2\end{array}$ \\
\hline G4 & $\begin{array}{l}\text { 【Sitting position Possible90\%】【Neck control Possible90\%】 } \\
\text { 【Communication method Speaking, Gestures and signs, Facial } \\
\text { expressions same percentage】【Need medical care20\%】 } \\
\text { 【Informed of excretion No Sign60\%】【Excretion disability30\%】 }\end{array}$ & $\begin{array}{c}110.3 \mathrm{~cm} \\
\left(80^{-} 150\right) \\
18.1 \mathrm{~kg} \\
\left(7.6^{-} 40.0\right) \\
\end{array}$ & $\begin{array}{c}7.5 y e a r s \text { old } \\
(2-15) \\
\text { Boy: Girl }=3: 2\end{array}$ \\
\hline I/D & $\begin{array}{l}\mid \text { 【Sitting position Possible 100\%】【Neck control Possible 100\%】 } \\
\text { 【Communication method Speaking, Gestures and signs】 } \\
\text { 【Informed of excretion Sign-beforehand】【Medical care } \\
\text { Unnecessary 】[Excretion disability20\% 】 }\end{array}$ & $\begin{array}{c}135.2 \mathrm{~cm} \\
\left(74^{-186)}\right. \\
36.3 \mathrm{~kg} \\
\left(7.3^{-115)}\right.\end{array}$ & $\begin{array}{c}\text { 10.4years old } \\
\quad(1-17) \\
\text { Boy: Girl=7:3 }\end{array}$ \\
\hline
\end{tabular}

Table 5 Presence of excretion disability and use of diapers (unit:people, Blank $=0$ )

\begin{tabular}{|c|c|c|c|c|c|c|c|c|}
\hline GROUP & Diaper ues $\begin{array}{c}\text { Excretion } \\
\text { disability }\end{array}$ & & Yes & & No & & nown & Total \\
\hline \multirow{3}{*}{$\begin{array}{l}\text { G1 } \\
P=-\end{array}$} & Yes & 49 & $(61.3 \%)$ & 29 & $(36.3 \%)$ & 2 & $(2.5 \%)$ & $80 \quad(100 \%)$ \\
\hline & No & & & & & & & \\
\hline & Total & 49 & $(61.3 \%)$ & 29 & $(36.3 \%)$ & 2 & $(2.5 \%)$ & $\begin{array}{ll}80 & (100 \%) \\
\end{array}$ \\
\hline & Yes & 34 & $(46.6 \%)$ & 35 & $(47.9 \%)$ & 7 & $\begin{array}{l}(5.5 \%) \\
\end{array}$ & $\begin{array}{ll}73 & (100 \%)\end{array}$ \\
\hline & No & & & & & & & \\
\hline & Total & 34 & $(46.6 \%)$ & 35 & $(47.9 \%)$ & 4 & $(5.5 \%)$ & $73 \quad(100 \%)$ \\
\hline \multirow{3}{*}{$\begin{array}{c}\mathrm{G} 3 \\
\mathrm{p}=0.000 \\
* * \\
*\end{array}$} & Yes & 29 & $(29.9 \%)$ & 29 & $(29.9 \%)$ & 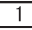 & $(1.0 \%)$ & $59(60.8 \%)$ \\
\hline & No & & (3.1\%) & 35 & $(36.1 \%)$ & & & $38(39.2 \%)$ \\
\hline & Total & 32 & $(33.0 \%)$ & 64 & $(66.0 \%)$ & 1 & $(1.0 \%)$ & $97 \quad(100 \%)$ \\
\hline \multirow{3}{*}{$\begin{array}{c}\text { G4 } \\
p=0.247\end{array}$} & Yes & 33 & $\begin{array}{l}(34.7 \%) \\
\end{array}$ & 50 & $(52.6 \%)$ & 4 & $\begin{array}{l}(4.2 \%) \\
\end{array}$ & $87(91.6 \%)$ \\
\hline & No & 4 & $(1.1 \%)$ & 7 & $(7.4 \%)$ & & & $\begin{array}{ll}8 & (8.4 \%) \\
\end{array}$ \\
\hline & Total & 34 & $(35.8 \%)$ & 57 & $(60.0 \%)$ & 4 & $(4.2 \%)$ & $\begin{array}{ll}95 & (100 \%) \\
\end{array}$ \\
\hline \multirow{3}{*}{$\begin{array}{c}\mathrm{I} / \mathrm{D} \\
\mathrm{p}=0.000 \\
* *\end{array}$} & Yes & 36 & (14.3\%) & 53 & $(21.0 \%)$ & 5 & $(2.0 \%)$ & $94(37.3 \%)$ \\
\hline & No & 18 & $(7.1 \%)$ & 139 & $(55.2 \%)$ & 1 & $(0.4 \%)$ & $158(62.7 \%)$ \\
\hline & Total & 54 & $(21.4 \%)$ & 192 & $(76.2 \%)$ & 6 & $(2.4 \%)$ & $\begin{array}{ll}252 & (100 \%) \\
\end{array}$ \\
\hline
\end{tabular}

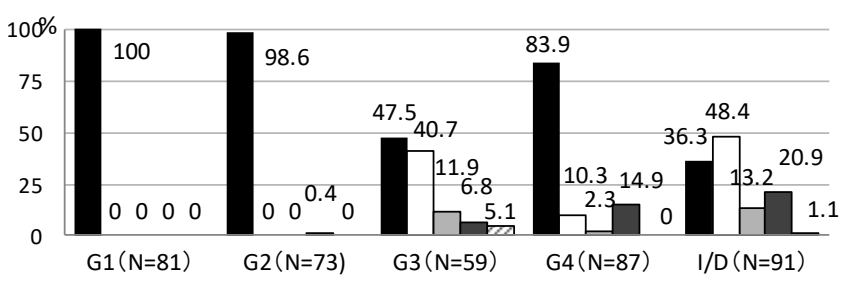

- All day $\square$ Only at night $\square$ Only when going out $\square$ Toilet training $\square$ Other Fig. 7 Diaper use situation (Multiple answer) 
とから, 成長や発達・生活場面に合わせた排泄環境について詳細な 分析を行う必要がある.

\section{5. 排泄状況を取り巻く多要因からの分析}

児は成長と発達に個人差があり，年齢のみで排泄実態を推定する ことは難しい，さらに，障害程度，身体機能及び排泄状況により排 泄環境が異なると考える。したがって，これまでの結果を踏まえ， 身体機能・意思伝達能力, 医療的ケアや排泄障害の有無, 排泄時の 告知等の情報をすべて考慮し, それぞれが抱えている問題とその関 係を把握する必要がある. そこで, 主成分分析のうち, 単位や次元 の異なるオブジェクト間の関係が理解しやすく, 数值変数間の線型 関係が問われないカテゴリカル主成分分析を用い:注15)，対象となる 児を身体状況及び排泄状況等の類似したグループに分ける。さら に，グループ別に排泄環境の分析を行い，問題を抽出する.

\section{1 カテゴリカル主成分分析を用いた児の分類}

アンケート結果で，身体機能や医療的ケアの有無，おむつ使用 率, 排泄告知などで排泄状況が著しく異なる〈知的・発達〉を含め ず注16)，〈重複〉及び〈身体〉のみ 353 人を対象にカテゴリカル主 成分分析を行った，分析に用いる説明变数は，「年齢」「体重」「医療 的ケアの有無」「側わんの有無」「立位」「座位」「寝返り」「首の座り」「意 思伝達方法」尿意」便意」「排泄障害の有無」の 12 項目注17) とする. 分析の結果をFig. 6 に示寸. ただし，「尿意」と「便意」は結合プロッ 卜間の空間距離が大きいほう注18)の「尿意」のみを表示, 以下同様 に，二次元プロットでは同一線上である「座位」「「医療的ケアの有 無」及び「排泄障害の有無」は「座位」のみを表示,「立位」と「首の座 り」は「立位」のみを表示する。
次に, 第 $\mathrm{I}$ 象限にプロットされた児のグループを $\mathrm{G} 1$, 第 II 象限 をG 3 , 第 III 象限を $\mathrm{G} 4$, 第 $\mathrm{IV}$ 象限を $\mathrm{G} 2$ とし，4 グループに分類す る. さらに, カテゴリカル主成分分析に含まなかった〈知的・発 達〉（以下「I/D」とする）を加え 5 分類で分析を行う注 16 ).

\section{2 各グループの基本属性}

各グループの人数は，G 1 が 82 人，G 2 が 74 人，G 3 が 100 人，G 4 が 97 人，I/Dが 259 人である. 各グループの特徴をTable 4 に示寸. G 1 は, 年齢が高く身体障害と知的障害はともに最重度, 排泄告知は ほとんどない児が多い，G 2 は, 年齢が低く身体障害と知的障害は ともに最重度, 排泄告知は一部でみられるがほとんどない児であ る. G 3 は, 年齢が高く身体障害は重度が多いが知的障害は中軽度 が多く, 排泄告知は知らせる児が多い，G4 は, 年齢が低く身体障 害と知的障害はともに重度が多く排泄告知もさまざまな児である. I/Dは，身体障害はなく知的障害が軽度から重度までさまざまであ り，排泄告知は知らせる児が多い.

\section{（1）排泄障害の有無とおむつ使用の有無}

排泄障害の有無とおむつ使用の有無をクロス集計しTable 5 に示 す．排泄障害がある児は，G1 では4 49 人 (61.3\%) であるが, G $2, G$ 3, G 4 及びI/Dでは $50 \%$ 以下である. おむつ使用の有無は, G 1 及び G 2 では全員がおむつを使用している.G3 では59人 (60.8\%)，G4 で は 87 人 $(91.6 \%)$ がおむつを使用し，I/Dでは 94 人 $(37.3 \%)$ と最も低 い，詳細をみると，G１では排泄障害があるためにおむつを使用す る児が49人 (61.3\%) と多いが，G 2 では排泄障害はないがおむつを使 用寸る児のほうが多く 35 人 ( $47.9 \%)$ となる. G 3 では排泄障害の有無 に関わらずおむつを使用する児が29人 (29.9\%)である.G4 では排泄 障害はないがおむつを使用する览が50人 $(52.6 \%)$ である.I/Dでは排

Table 6 Excretory place and excretion position (Urination $•$ Defecation) (unit:people, Blank=0)

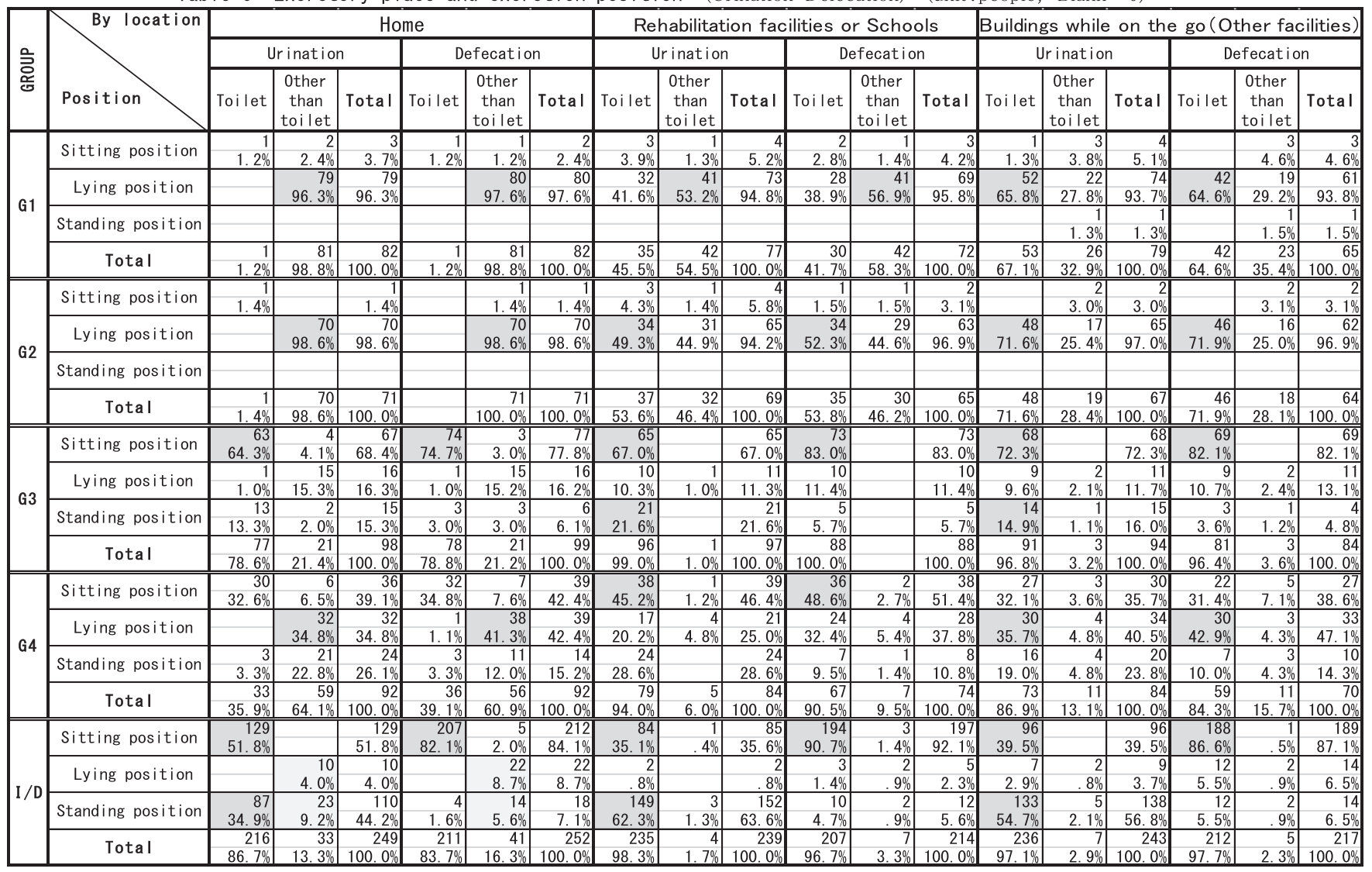


泄障害がなくおむつを使用する児は 53 人 $(21.0 \%)$ である.そこで， おむつを使用している時間帯をFig. 7 に示す．G1 及びG 2 では「一 日中」おむつを使用する览はほぼ全員であるが，G 3 及びI/Dでは 「一日中」おむつを使用する巟は $50 \%$ 以下に減少し，「外出時の み」や「就寝時のみ」におむつを使用する览が増加する，G４では 「一日中」おむつを使用する児が $80 \%$ 以上と多いが，トイレットト レーニング中が増加する.

\section{（2）排泄姿勢と排泄場所}

排尿・排便時の排泄姿勢を自宅, 通園 - 通学先及び外出先注 19$)$ 別 にみた結果と排泄場所を「トイレ」または「トイレ以外」かをみた結果

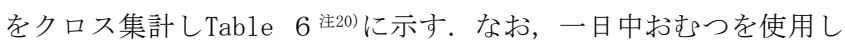
ている場合は，おむつ交換姿勢とおむつ交換場所とする.

G 1 では自宅でリビング・寝室など「トイレ以外」で排泄している 巟が排尿・排便とも 81 人 ( $98.9 \%)$ であり，外出先においても自家用 車内や救護室など「トイレ以外」で排泄している児が排尿で 26 人 (32. $9 \%$ 排便で 23 人 (35.4\%) みられる. G 2 も同様の傾向を示すが， G 3 及びI/Dでは「トイレ」での排泄が多くなる，G4では自宅では「ト イレ」で排泄している児が33人 $(35.9 \%)$ ，「トイレ以外」で排泄し ている览が59人 (64.1\%) である．

さらに詳細にみると, G 1 では自宅や通園・通学先は「トイレ以外 で臥位姿勢」で排尿する児の割合が高いが，外出先は「トイレ内で卧 位姿勢」の児の割合が高くなる，G２では自宅は「トイレ以外で臥位 姿勢」で排泄する児の割合が高いが，通園・通学先は「トイレ内で卧 位姿勢」の児の割合が高くなる，一方，G3ではすべての場所におい て「トイレ内で座位姿勢」で排泄する児の割合が最も高い，G4では自 宅及び外出先は臥位姿勢で排泄している览の割合が高いが，通園・ 通学先は「トイレ内で座位姿勢」の割合が高くなり, 場所ごとに排泄
姿勢の変化がみられるＩ/Dでは自宅は「トイレ以外で卧位姿勢」 で排泄する児がわずかに見られるが，通園・通学先ではほとんどい なくなり,「トイレ内の座位または立位姿勢」の割合が高くなる.

排尿と排便の相違点について見ると, 排泄姿勢には男女差がある ものの G 3 と I/Dでは排便時は「座位姿勢」が多く, 排尿時は「立位 姿勢」が増える. 排泄場所はいずれのグループとも排尿場所と排便 場所で違いはない.

\section{3 各グループの排泄環境の実態}

\section{（1）排泄時使用する設備・用具類}

排泄時に使用する便器及び污物流しなどの建築設備, 幼児用補助 便座などの一般的な用具類, 及び障害を考慮した姿勢保持機能付き 便座など福祉用具類の使用状況を「自宅」「通園・通学先」「外出先」の

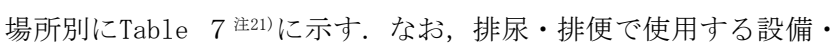
用具類が小便器類以外あまり相違がみられなかったため排尿時に使 用寸る設備・用具類のみ示寸. また, 本項では医療的ケアに使用す る用具類注 22$)$ を除く.

i) 便器等 $G 1$ 及びG 2 ではトイレ以外で排泄する览が多いことか ら便器の使用が少なく, 「通園・通学先」でわずかに使用する便 器の種類が増える，G 3, G 4 及びI/Dでは「自宅」より「通園・通 学先」で使用する便器の種類が増え, 排尿では小便器の利用があ る.

ii）移乗・移動補助用具等 G1 では「通園・通学先」で「トイレ用車 いす」を使用する児がいるが，5分類いずれも移乗用具類の使用 は少ない，G4及びI/Dでは「自宅」で踏み台」の使用がある.

iii) 姿勢保持用具等 G 1, G 2 は「便器」を使用する児が少なく, ま た，I/Dでは排泄自立している児が多く，姿勢保持用具等の使用 はほとんどない。「自宅」で「幼児用補助便座」を使用している児

Table 7 Equipment and tools used for excretion

(Multiple answer) $($ Blank $=0) *$ Rehabilitation facilities or Schools $=$ Schools, $* *$ Buildings while on the go (Other facilities) $=$ Other

\begin{tabular}{|c|c|c|c|c|c|c|c|c|c|c|c|c|c|c|c|c|c|}
\hline \multirow{2}{*}{\multicolumn{3}{|c|}{ Equipment and tools }} & \multicolumn{3}{|c|}{ G1 } & \multicolumn{3}{|c|}{ G2 } & \multicolumn{3}{|c|}{ G3 } & \multicolumn{3}{|c|}{ G4 } & \multicolumn{3}{|c|}{ I/D } \\
\hline & & & \multirow{2}{*}{\begin{tabular}{|c|}
$\frac{\mathscr{E}}{\text { 오 }}$ \\
$12.1 \%$
\end{tabular}} & \multirow{2}{*}{\begin{tabular}{|l|} 
* $\frac{0}{0}$ \\
$\frac{0}{0}$ \\
c \\
$5.9 \%$ \\
\end{tabular}} & $\begin{array}{l}* \text { 㐫 } \\
* \\
* \\
\end{array}$ & $\begin{array}{l}\text { Ф્犬 } \\
\text { 오 }\end{array}$ & $\begin{array}{l}\frac{\infty}{\circ} \\
\frac{0}{0} \\
\dot{c} \\
\end{array}$ & 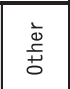 & $\begin{array}{l}\text { Ð } \\
\text { 호 }\end{array}$ & $\begin{array}{l}\frac{\infty}{0} \\
\frac{0}{0} \\
\dot{c}\end{array}$ & $\begin{array}{l}\frac{ \pm}{ \pm} \\
\frac{1}{0}\end{array}$ & $\begin{array}{l}\text { Ф્ } \\
\text { 호 }\end{array}$ & $\begin{array}{l}\frac{0}{0} \\
\vdots \\
\frac{0}{0} \\
\dot{s}\end{array}$ & 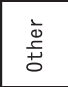 & $\begin{array}{l}\text { 틀 } \\
\text { 포 }\end{array}$ & $\begin{array}{l}\frac{\infty}{0} \\
\dot{0} \\
\frac{0}{0} \\
\infty\end{array}$ & 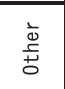 \\
\hline \multirow{12}{*}{\begin{tabular}{l}
$\frac{\infty}{3}$ \\
0 \\
$\stackrel{0}{0}$ \\
$\stackrel{0}{0}$ \\
\hdashline- \\
$\circ$
\end{tabular}} & \multirow{3}{*}{$\begin{array}{l}\text { Western- } \\
\text { style toilet }\end{array}$} & Western-style toilet bow I & & & 4. $2 \%$ & $14.7 \%$ & $1.7 \%$ & $3.0 \%$ & $96.7 \%$ & $64.2 \%$ & $79.2 \%$ & $71.4 \%$ & $32.6 \%$ & $48.8 \%$ & $95.9 \%$ & $57.0 \%$ & $75.6 \%$ \\
\hline & & Western-style toilet bow I (for children) & & & & $2.9 \%$ & 6. $8 \%$ & $1.5 \%$ & & 8. $4 \%$ & 2. $1 \%$ & $2.6 \%$ & $34.8 \%$ & $11.0 \%$ & $4 \%$ & $15.6 \%$ & $6.9 \%$ \\
\hline & & Western-style toilet bowl (for wheelchairs) & & & $1.4 \%$ & & & $1.5 \%$ & & $12.6 \%$ & $14.6 \%$ & & 3. $4 \%$ & $3.7 \%$ & $4 \%$ & $4 \%$ & $2.0 \%$ \\
\hline & & Japanese-style toilet bow I & & & & & & & $1.1 \%$ & & & & 2. $2 \%$ & & $4 \%$ & $2.9 \%$ & $5.3 \%$ \\
\hline & & Long toilet bowl & & $3.9 \%$ & & & $3.4 \%$ & & & $2.1 \%$ & $1.0 \%$ & & $10.1 \%$ & & & $1.6 \%$ & $8 \%$ \\
\hline & Special & Toilet bowl embedded in floor & & & & & & & & & & & & & & $1.6 \%$ & \\
\hline & & Floor-elevated toilet bowl & & & & & & & & 1. $1 \%$ & & & & & $4 \%$ & & \\
\hline & & Commode & & & & & & & $1.1 \%$ & & & & 1. $1 \%$ & & & & \\
\hline & Portable & Bedpan & & & & $2.9 \%$ & & & & & & $3.9 \%$ & 1. $1 \%$ & & $1.6 \%$ & & \\
\hline & & Chamber pot/Urine-collecting pot & $6.1 \%$ & $5.9 \%$ & 2. $8 \%$ & $2.9 \%$ & $5.1 \%$ & & $5.6 \%$ & 4. $2 \%$ & 2. $1 \%$ & & $1.1 \%$ & & & & \\
\hline & & Urinal (for adults) & $3.0 \%$ & 2. $0 \%$ & & & & & & $13.7 \%$ & $10.4 \%$ & & 2. $2 \%$ & & $2.4 \%$ & $23.4 \%$ & $27.2 \%$ \\
\hline & Urinal & Urinal (for children) & & & & & $1.7 \%$ & & & 5. $3 \%$ & 7. $3 \%$ & & $10.1 \%$ & 1. $2 \%$ & $4 \%$ & $16.4 \%$ & $13.4 \%$ \\
\hline ii $\mathrm{Ar}$ & incillary & Stepstool & & & & & & & $1.1 \%$ & & & 7. $8 \%$ & $4.5 \%$ & & 4. $1 \%$ & & \\
\hline transfer & $r$ or move & Wheelchair for toilet & & 5. $9 \%$ & & & & & $1.1 \%$ & 2. $1 \%$ & & & 1. $1 \%$ & & & & \\
\hline & & Handrail (Horizontal) & & & & & & & $21.1 \%$ & $23.2 \%$ & $19.8 \%$ & $7.8 \%$ & $7.9 \%$ & 7. $3 \%$ & & $4 \%$ & $4 \%$ \\
\hline & Handrail & Handrail (Vertical) & & & & & & & $10.0 \%$ & $10.5 \%$ & $10.4 \%$ & $1.3 \%$ & 3. $4 \%$ & $3.7 \%$ & & & \\
\hline$\stackrel{\infty}{\infty}$ & & Backrests & & & & & & & $2.2 \%$ & & & & $3.4 \%$ & & $4 \%$ & & \\
\hline$\circ$ 인 & Maintain & Tools to support front to maintain posture & & & & & $1.7 \%$ & & $1.1 \%$ & $1.1 \%$ & & & 2. $2 \%$ & & & & \\
\hline$\subseteq$ & sitting & Belts to fix the body to maintain posture & & 2. $0 \%$ & & & $1.7 \%$ & & & 1. $1 \%$ & & & 2. $2 \%$ & & & & \\
\hline$\frac{0}{\pi}$ & & Toilets with tools to maintain posture & $3.0 \%$ & & & & $1.7 \%$ & & 2. $2 \%$ & 4. $2 \%$ & & $1.3 \%$ & 3. $4 \%$ & & & & \\
\hline$\therefore \simeq$ & Toilet & Soft toilet seat & & & & & & & $1.1 \%$ & & & $1.3 \%$ & $1.1 \%$ & & & & \\
\hline$\stackrel{\mathbb{W}}{E}$ & seats & Ancillary toilet seat for young $c$ & & & & 14. $7 \%$ & $1.7 \%$ & & $6.7 \%$ & 4. $2 \%$ & 4. $2 \%$ & $41.6 \%$ & $13.5 \%$ & $4.9 \%$ & 7. $3 \%$ & & $2.0 \%$ \\
\hline & & Baby crib & $3.0 \%$ & $2.0 \%$ & $2.8 \%$ & $14.7 \%$ & $6.8 \%$ & $20.9 \%$ & & & & & $1.1 \%$ & $8.5 \%$ & $4 \%$ & & $8 \%$ \\
\hline & & Diaper changing table for baby & & 2. $0 \%$ & 7. $0 \%$ & & $18.6 \%$ & $64.2 \%$ & & $1.1 \%$ & $1.0 \%$ & & 2. $2 \%$ & $39.0 \%$ & & & 7. $3 \%$ \\
\hline l. & anging & Diaper changing table for adult & & $47.1 \%$ & $88.7 \%$ & & 32. $2 \%$ & 73. $1 \%$ & & $10.5 \%$ & $17.7 \%$ & & 7. $9 \%$ & $47.6 \%$ & & & $3.3 \%$ \\
\hline clotne & sh daper & Mat to be laid on floor & $60.6 \%$ & $29.4 \%$ & $15.5 \%$ & $58.8 \%$ & 33. $9 \%$ & $7.5 \%$ & 1. $1 \%$ & & 2. $1 \%$ & $11.7 \%$ & $16.9 \%$ & $1.2 \%$ & 2. $4 \%$ & $4 \%$ & \\
\hline & & Cloth-changing table (for standing position) & & 5. $9 \%$ & 4. $2 \%$ & & $6.8 \%$ & $6.0 \%$ & & $3.2 \%$ & 4. $2 \%$ & & & $4.9 \%$ & & & $2.0 \%$ \\
\hline & & Hot water washing closet seat & $3.0 \%$ & & & & & & $4.4 \%$ & & & & & & $1.2 \%$ & & $4 \%$ \\
\hline Tools & |lp & Portable bidet & 3. $0 \%$ & & & $2.9 \%$ & & $3.0 \%$ & & & & & & & & & \\
\hline with c & lean-up & Flush (for clean-up of excrement) & 3. $0 \%$ & 2. $0 \%$ & $1.4 \%$ & & & & $1.1 \%$ & & & $1.3 \%$ & & $1.2 \%$ & & & \\
\hline & & other tools & $12.1 \%$ & $5.9 \%$ & $8.5 \%$ & $11.8 \%$ & $5.1 \%$ & $3.0 \%$ & $1.1 \%$ & & $1.0 \%$ & $2.6 \%$ & & $1.2 \%$ & $4 \%$ & & \\
\hline & & ber of respondents: people/\% & 33 & 51 & 71 & 34 & 59 & 67 & 90 & 95 & 96 & 77 & 89 & 82 & 246 & 244 & 246 \\
\hline
\end{tabular}


はG 2 が $14.7 \%$ ，I/Dが7.3\%である. G 3 及びG 4 では「手すり」の使 用が多く, 座位保持用の用具類も「自宅」より「通園・通学先」の ほうが使用している児の割合が高い，G4 では「自宅」で「幼児用 補助便座」を利用している児の割合が $41.6 \%$ と他グループに比較 してかなり高い.

iv）着脱衣・おむつ交換用具等 G1 及びG 2 では「自宅」で「床に敷 くマット類」を使用している児の割合がそれぞれ $60.6 \% ， 58.8 \%$ と 高く, 「通園・通学先」及び「外出先」は「大人用おむつ交換台」を 使用している児の割合が高い.さらに，G2 では「外出先」は「大 人用おむつ交換台」の他に「乳幼児用おむつ交換台」を使用してい る児の割合も $64.2 \%$ 高くなる. G 3 及びG 4 では「自宅」でほとん ぞ用具を使用していないが，G4では「外出先」で「大人用おむつ 交換台」を使用している児の割合が $47.6 \%$ と高い. I/Dでは「外出 先」で乳幼児用おむつ交換台」を使用している児がわずかにいる.

v ）後始末用具等 G1 では「污物流し」などの使用はあるが，他グ ループではほとんど利用している用具はない，G 3 では「温水洗浄 便座」を使用している览がわずかにいる.

\section{（2）住宅内排泄環境整備の実態}

排泄に関する住宅改修あるいは工夫を「実施, 現在も利用」実 施，現在は不利用」「未実施」に区分LFig. 8 に示す.さらに，住宅 改修あるいは工夫の内容を利用状況別にTable 8 に示寸.

G 1，G 2 及びI/Dでは住宅改修あるいは工夫をほとんど実施して いないが，G3では28人 (28.0\%)，G4では11人（12.2\%）が「実施 し, 現在も利用」している. その内容の多くは「手すりの設置」で あり，G 3 が23人 (82.1\%)，G4が9人（81.9\%）である。一方，G 1 及びI/Dでは「実施，現在は不利用」のほうが現在も利用している児 より多く，それぞれ 9 人 (11.4\%)，7人 (2.8\%) である. その内容

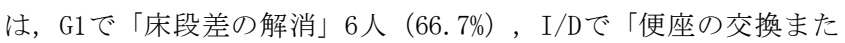
は追加」5人 $(71.4 \%)$ が最も多く, 不利用の理由は, G1で「体重が 重くなったから」「身長が伸びたから」「トイレを使わないほうがすべ ての点で楽だから」などであり，I/Dでは「自分でできるようになっ たから」である.

\section{（3） 介助者の状況とトイレでの排泄希望と実際の排泄場所}

介助者注23)が自宅のトイレでの排泄を希望しているか否かについ て，「希望している」「希望していない「わからない」の 3 段階に区分 した結果と，実際の自宅での排泄場所をTable 9 に示す. 介助者の 性別は，5分類いずれも「女性」が $90 \%$ 以上である. なお，前項 5 . 2.2 から，排泄場所に排尿・排便でわずかの差しかみられなかっ たため, 排泄場所については排尿場所とし，本項では介助者（母親） の一人介助かつ一般的な設備が主である自宅について示す.

G 1 ではトイレでの排泄を希望していない介助者が多く, その理 由として一番多い回答は，「介助が大変だから」が 30 人 (51.7\%) で ある. 実際の排泄場所もリビング・寝室など「トイレ以外」で排泄す る児が 57 人 $(74.0 \%)$ である. G 2 ではトイレでの排泄を希望している が実際の排泄場所は「トイレ以外」で排泄する览が 32 人 (45. 1\%)であ る.G3 ではトイレでの排泄を希望していて，実際にトイレで排泄 している児の割合が 72 人 (78.3\%) と最も高い，G4ではトイレでの排 泄を希望しているが，実際の排泄場所は「トイレ以外」で排泄してい る児のほうが 48 人 $(53.3 \%)$ と高い. I/Dではトイレでの排泄を希望 し，実際にトイレで排泄している児が206人 (84.8\%) と最も高い.

\section{6. 考察}

\section{1 各グループ別の考察}

\section{（1）G1 (高年齢, 身体障害及び知的障害ともに最重度, 医療的ヶア多)}

平均体重は身長に対して比較的軽く, 排泄告知は「しらせない览 が約70\%，座位が「できない览が約 $80 \%$ である。全員がおむつを一日 中使用し, 排泄障害や医療的ケアが必要な児が多い. 基本的には, トイレに移動し，おむつ交換及び污物処理を行うことが望ましい. そのためには，トイレ内または隣室におむつ交換スペース及び污物 処理用の設備を設け，児に合わせた移動用具または移動・移乗用の リフトなど福祉用具の導入を検討することが重要である.

一方，排泄のたびに移動することで身体的負荷が生じる場合に は，次善の策としてその場で污物処理を行いやすい環境やプライバ

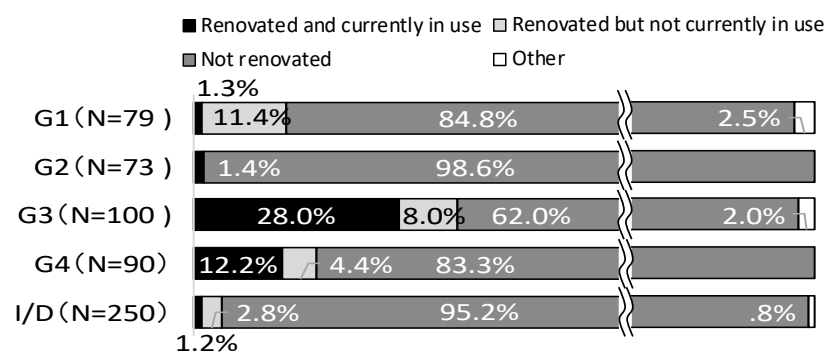

Fig. 8 House remodeling and use of devices concerning excretion $(p=0.000 * *)$

Table 8 Contents of housing renovation (Multiple answer) (Blank=0)

\begin{tabular}{|c|c|c|c|c|c|c|c|c|c|c|}
\hline & \multicolumn{5}{|c|}{$\begin{array}{l}\text { Renovated and } \\
\text { currently in use }\end{array}$} & \multicolumn{5}{|c|}{$\begin{array}{l}\text { Renovated but } \\
\text { t currently in use }\end{array}$} \\
\hline & G1 & $\mathrm{G} 2$ & G3 & G4 & I/D & G1 & $\mathrm{G} 2$ & G3 & G4 & $\mathrm{I} / \mathrm{D}$ \\
\hline Change door & $100^{1}$ & & $\begin{array}{l}10 \\
35\end{array}$ & 9 & & $\mid \begin{array}{r}5 \\
55\end{array}$ & & & $250 \%$ & $8.6 \%$ \\
\hline Spread the entrance & $100 \%$ & & $\begin{array}{r}5 \\
17.9 \%\end{array}$ & $9.1 \%$ & & $\left|\begin{array}{r}5 \\
55.6 \%\end{array}\right|$ & & & $50.0 \%$ & \\
\hline $\begin{array}{l}\text { Extend the size of } \\
\text { the toilet }\end{array}$ & $\begin{array}{r}100 \% \\
100 \%\end{array}$ & & $\begin{array}{r}4 \\
14.3 \% \\
\end{array}$ & & $50.0 \%$ & $\begin{array}{r}3 \\
33.3 \% \\
\end{array}$ & & & & \\
\hline $\begin{array}{l}\text { Exchange of toilet } \\
\text { bowl }\end{array}$ & & & $\begin{array}{r}2 \\
7.1 \% \\
\end{array}$ & & $50.0 \%$ & & & & & \\
\hline $\begin{array}{l}\text { Exchange and addition } \\
\text { of toilet seat }\end{array}$ & & & $7.1 \%$ & $18.2 \%$ & $50.0 \%$ & $22.2 \%$ & & $25.0 \%$ & $25.0 \%$ & $71.4 \%$ \\
\hline $\begin{array}{l}\text { Eliminate steps on } \\
\text { the floor }\end{array}$ & $100 \%$ & & $25.0 \%$ & $18.2 \%$ & & $\begin{array}{r}6 \\
66.7 \% \\
\end{array}$ & & 25.08 & $\begin{array}{r}1 \\
25.0 \% \\
\end{array}$ & \\
\hline Attach a handrail & $100 \%$ & & 82. $1 \%$ & $81.8 \%$ & & $11.1 \%$ & & $50.0 \%$ & $75.0 \%$ & \\
\hline Attach the lift & & $100^{\circ}$ & $\begin{array}{r}1 \\
3.6 \%\end{array}$ & & & $11.1 \%$ & & & & 14. $3 \%$ \\
\hline $\begin{array}{l}\text { Use a wheelchair for } \\
\text { a toilet }\end{array}$ & & & 3. $6 \%$ & & & $11.1 \%$ & & & & \\
\hline Other & & $100 \%$ & $7.1 \%$ & $27.3 \%$ & & 33. $3 \%$ & & $50.0 \%$ & & $\begin{array}{r}33 \\
42.9 \% \\
\end{array}$ \\
\hline Total (unit: people) & 1 & 1 & 28 & 11 & 2 & 9 & 0 & 8 & 4 & 7 \\
\hline
\end{tabular}

Table 9 Excretion in the toilet and actual excretion place (Blank=0)

\begin{tabular}{|c|c|c|c|c|c|}
\hline GROUP & Place $\quad$ Desired & Desired & Not desired & Unknown & Total \\
\hline \multirow{3}{*}{$\underset{\mathrm{p}=0.847}{\mathbf{G 1}}$} & Toilet & & $1 \quad(1.3 \%)$ & & $1 \quad(1.3 \%)$ \\
\hline & Other than toilet & $15(19.5 \%)$ & $57(74.0 \%)$ & $4(5.2 \%)$ & $76(98.7 \%)$ \\
\hline & Total & $15(19.5 \%)$ & $58(75.3 \%)$ & $4(5.2 \%)$ & $77(100 \%)$ \\
\hline \multirow{3}{*}{$\begin{array}{c}\text { G2 } \\
\mathrm{p}=0.558\end{array}$} & Toilet & $\begin{array}{ll}1(1.4 \%) \\
\end{array}$ & & & $1 \quad(1.4 \%)$ \\
\hline & Other than toilet & $32(45.1 \%)$ & $25(35.2 \%)$ & $13(18.3 \%)$ & $70(98.6 \%)$ \\
\hline & Total & $33(46.5 \%)$ & $25(35.2 \%)$ & $13(18.3 \%)$ & $71(100 \%)$ \\
\hline \multirow{3}{*}{$\begin{array}{c}\text { G3 } \\
p=0.000 * *\end{array}$} & Toilet & $72(78.3 \%)$ & & & $72(78.3 \%)$ \\
\hline & Other than toilet & $10(10.9 \%)$ & $10(10.9 \%)$ & & $20(21.7 \%)$ \\
\hline & Total & $82(89.1 \%)$ & $10(10.9 \%)$ & & $92(100 \%)$ \\
\hline \multirow{3}{*}{$\begin{array}{c}\mathrm{G} 4 \\
\mathrm{p}=0.031 *\end{array}$} & Toilet & $30(33.3 \%)$ & & & $30(33.3 \%)$ \\
\hline & Other than toilet & $48 \quad(53.3 \%)$ & $9(10.0 \%)$ & $3(3.3 \%)$ & $60(66.7 \%)$ \\
\hline & Total & $78(86.7 \%)$ & $9(10.0 \%)$ & $3(3.3 \%)$ & $90(100 \%)$ \\
\hline \multirow{3}{*}{$\begin{array}{c}\text { I/D } \\
p=0.104\end{array}$} & Toilet & \begin{tabular}{|ll}
$206(84.8 \%)$ \\
\end{tabular} & $2(0.8 \%)$ & $10 .(0.4 \%)$ & $209(86.0 \%)$ \\
\hline & Other than toilet & $32(13.2 \%)$ & $2(0.8 \%)$ & & $34(14.0 \%)$ \\
\hline & Total & \begin{tabular}{|ll}
238 & $(97.9 \%)$ \\
\end{tabular} & $4(1.6 \%)$ & $1(0.4 \%)$ & $243(100 \%)$ \\
\hline
\end{tabular}


シー確保のための目隠しの設置, 使用済みおむつを捨てるための介 助者の動線確保などが必要となる. また, おむつ交換場所をみると 「トイレ以外」が多く, 自宅では $90 \%$ 以上の児がリビング・寝室な ぞ, 通園・通学先でも約半数の览が教室などでおむつ交換を行って おり, 自由記述でも「おむつ交換時のにおいが強烈」水様便でズボ ンまで污れてしまいその污物処理が大変」といった意見が出されて いる. 以上のことから，G1では介助者の視点で污物処理に必要な 動線や間取り, 手洗器及び污物処理用設備の設置, 介助スペースや おむつ保管場所の確保などの住環境整備やおむつ交換場所でのプラ イバシーへの配慮が重要と考える.

外出先では, 自由回答において「大人用おむつ交換台がない, ま たは, 設置場所が少ないので, 自家用車内で交換する, 我慢して帰 宅する」といった問題があげられ，公共施設等において大人用おむ つ交換台設置箇所の増加など外出時の排泄環境も合わせて考える必 要がある.

\section{（2）G2（低年齢，身体障害及び知的障害ともに最重度,} 医療的ヶア半数程度)

平均身長と体重が各グループの中で最も小さく, 座位は「できな い児が約50\%, 排泄告知は「知らせない児の割合がG 1 より少なく約 60\%である. 排泄障害はないがおむつを使用している児が半数近く いる．トイレでの排泄を希望している介助者の割合が高いが，実際 にはトイレ以外で排泄(おむつ交換を含む)を行っている．しかし， 通園・通学先ではトイレ内でおむつ交換する児が自宅より多く, 排 泄姿勢を見ると通園・通学先では自宅より「座位姿勢」がわずかに増え ている. 一方, 自宅で使用する設備・用具類は一般的な便器や幼坚 用補助便座のみである. したがって, 環境が整備されることでトイ レでのおむつ交換や排泄が可能となる児が存在すると考える. 以上 のことから, 日中の居場所とトイレとの位置関係やおむつ交換場所 までの移動距離・移動方法, トイレ内の広さ, 姿勢保持方法など介 助負担を軽減するための環境整備を行うことが重要である.

外出先では, G 1 同様におむつ交換台の利用が多く, 自由回答で は，大人用おむつ交換台がないために「足がはみ出した状態で乳児 用のおむつ交換台に体だけ乗せて利用している」といった問題があ げられている.

\section{（3）G3 (高年齢，身体障害重度及び知的障害中軽度もしくは無， 医療的ヶアほとんど無）}

平均身長と体重が比較的大きく, 座位が「できる」巟が約 $80 \%$ と多 く, 排泄の告知は「ほとんど事前に知らせる」児が約 $70 \%$ ある。.トイ レでの排泄が可能な児が多く, 実際に排泄に関する住宅改修等を 行った児が約 $30 \%$ と他のグループより多い. また，排泄時に使用す る設備・用具類では, 「自宅」「通園・通学先」「外出先」のいずれにお いても手すりを使用しており，トイレで座位もしくは立位での排泄 が可能となっている. 自由回答においても「便座に座るときにどこ かに支えがないと座れない」便座両側に手すりと背もたれがあると 安定して排泄できる」などの意見がある. 以上のことから，G3で は, 手すりや背もたれなど福祉用具を活用し, 排泄自立のための排 泄環境整備が重要と考える.

外出先では, 外出時のみおむつを使用する览もみられ, 自由回答 においても「使用できるトイレの設置数が少ない，でも漏らしたく ない」といった失敗を予防をする目的を含め, すぐに使用できるト
イレを見つけることができない, 自宅と環境が異なるなど, 外出先 での排泄環境が排泄方法に影響していると考える.

\section{（4）G4（低年齢，身体障害及び知的障害ともに重度， 医療的ヶアほとんど無）}

平均身長と体重が比較的小さく，座位が「できる」児が約 $90 \%$ とと んどであり, 排泄の告知は「知らせない览が約 $60 \%$ と低い. G 2 と同 様に排泄障害はないがおむつを使用する児が半数近くいる．使用す る設備・用具類では自宅は幼児用補助便座を使用している児が $40 \%$ 以上と多いが, 通園・通学先ではさまざまな便器類や姿勢保持類を 使用している. 実際に自宅と通園・通学先, 排尿と排便とでは排泄姿 勢や排泄場所が異なる児がいるため, 環境が整えばトイレでの排泄 が可能となり, 児の成長や発達に合わせて用具等を整備することで 排泄自立の可能性が高い. しかし, 自宅で使用しているのは一般的 な幼児用補助便座が主であり, 姿勢保持のために介助者が支えてい ると考えられ, 介助者の負担が大きい. 以上のことから, G4 では 自宅でも通園・通学先と同様, 排泄動作の獲得に向け必要となる姿 勢保持用具類を成長や発達に合わせ適切に整備し, 介助負担を軽減 のための排泄環境整備が重要であると考える.

外出先では, おむつ交換台を使用している览が多く, トイレット トレーニング中の期間は, 外出先に自宅と同様の環境を求めること が難しい. 自由回答においても「手に届くものを触って口に入れる など落ち着いて排泄やおむつ交換ができない「補助便座を置いてほ しい, 持ち歩くのが大変」といった意見が出され, 外出先での排泄 環境はおむつ交換台の不足や児の使用に適した補助便座や背もたれ などの設備不足といった問題を抱えている.

\section{（5）I/D（身体障害無，知的障害又は発達障害中軽度から 最重度，医療的ヶア無）}

おむつ使用率は低く, おむつ使用している児の半数近くが就寝 時のみ」の使用であり, 多くはトイレでの排泄が可能である. 排泄 場所別に使用寸る設備・用具類に顕著な差異はないが, 自宅では座 位もしくは臥位姿勢で排尿する児が通園・通学先では立位姿勢に変 化することから, 男児においては小便器が排尿しやすいと考える. その他, 自由回答において「気が付くとおむつを食べている」「污いとい う概念がないため, おむつにした便を触る」といった行動または意識に 関する課題があげられ，他のグループとは別の問題を抱えている. これらの解決方法として, 強いこだわり, 多動, 感覚過敏, 異食や ろう便注24) など行動特性に配慮し住環境を整備することが重要であ る8）9）が，I/Dの住宅改修あるいは工夫のほとんどが幼児用補助便 座の設置であり, 行動特性に配慮した住宅改修等を行っている児が ほとんどいない, 以上のことから, 重度の知的障害または発達障害 がある児に配慮し, 排泄しやすい環境を整備し, 便器周辺が污れて も掃除しやすい材質にするなど介助負担を軽減するための排泄環境 整備が重要と考える.

外出先では, 自由回答において「操作ボタン類がわかりづらい」 「ハンドドライヤーの音が怖くて一人でトイレに入れないなどがあ げられ，排泄環境が動作に影響を与えていると考える.さらに， 「お尻がうまく拭けない, 便器周辺を污す」「異性介助注25)が多く, 外出 先で一緒にトイレに入りづらいといった意見がある. 以上のことから， 洗浄ボタンやスイッチ類のわかりや寸さ及びマーク・サイン等の統 一, 音などの刺激を少なくする, お尻拭き等介助スペースの確保や 
異性介助でも容易に出入りできるトイレの設置といった配慮を行う 必要がある。

\section{2. 全体の考察}

\section{（1）おむつ使用に関する配慮}

排泄障害があり，排泄の告知もなく，おむつを使用する児への配 慮として, 污物処理の動線やおむつ保管場所，おむつ交換のための 介助スペースの確保など介助者の視点による排泄環境整備が重要と 考える．排泄教育やプライバシーの観点からできる限りトイレでの おむつ交換が望まれるが，リビング・寝室，教室などトイレ以外て おむつ交換をする児も多い，その際には，目隠しやパーテーション などプライバシーへの配慮やおむり交換時の消臭・脱臭など衛生面 における配慮も重要である.

\section{(2)住宅内排泄環境整備の重要性}

排泄障害がなくてもおむつを使用している览が多いこと，自宅よ りも通園・通学先のほうがトイレで使用する設備や用具の種類が増 えることを考慮すると, 環境を整備することでトイレでの排泄が可 能な巟が存在する．しかし，トイレでの排泄希望は高いにもかかわ らず，リフトや車いすなど移乗・移動用具の活用や排泄に関する住 宅改修等を行っている児は非常に少ない，また，トイレでの排泄を 希望しない理由の一つにトイレまでの移動介助やトイレでの姿勢保 持介助といった「介助が大変だから」があげられている.

これらは，日中の居場所からトイレまでの動線の確保，姿勢保持 機能付き便座など福祉用具の活用といった，介助負担を軽減するた めの住環境整備に関する知識や情報が少ない，住環境整備には費用 が伴い，成長や発達に合わせて览が利用できる住宅改修に関する支 援制度や福祉用具のレンタル制度がないことなどが要因と考える. 自由回答においても情報・知識不足や費用面・経済的問題があげら れている。

\section{(3) 外出時の排泄環境整備}

重度障害児はおむつを使用している場面が多く，外出時におむつ 交換台を使用する児が多い，自由回答では，乳幼児用おむつ交換台 は小さ過ぎて使用できない，大人用おむつ交換台の設置が少ない， おむつ交換台があってもトイレが狭くて使用できないといった外出 先に関する設備・用具類など排泄環境の問題点が多くあげられてい る.また，不特定多数が利用する多機能トイレでは自宅と同様に 個々に合わせた環境を求めることは難しく，トイレットトレーニン グ中や姿勢保持の面でさまざまな児に配慮した設備・用具が不足し ている. 現実的には，一般的な幼児用補助便座に併せて現在ある手 すりや背もたれに汎用性のある軽微な支持具を付加する等が考えら れる.さらに，児が幼いころは気にならなくても学齢が上がるにつ れ異性介助でトイレに入りにくいなど, 現状の多機能卜イレにおい ては児に配慮した環境が不十分であり課題が多い.

\section{7. まとめと今後の課題}

本研究では，排泄動作を獲得するために手すりや姿勢保持用具を 成長・発達に合わせ使用し排泄環境を整えることで，トイレにおけ る排泄が可能となる重度障害児がいることを示した。また，重度障 害児がおむつを使用する場面を想定し，おむつ交換場所の配慮や污 物処理等のしやすさなど介助者の視点での排泄環境整備の重要性を 示した。さらに，外出先における大人用おむつ交換台の設置場所が
少ないことや，排泄場所ごとに異なる排泄環境の実態を明らかにし た。しかし, アンケート調査のみでは, 二分脊椎症注26) や進行性疾 患など個別の障害特性への配慮や成長・発達に合わせた排泄環境及 び排泄状況の経年変化を見ることができない，今後は，在宅訪問調 査注27)，により得られている児の住宅内排泄環境を時系列に沿って詳 細に分析し, 成長や発達に合わせた排泄環境整備を明らかにするこ とが重要と考える.

\section{謝辞}

本研究の調查にあたり，アンケート及び訪問調查にご協力いただ いた障害のある皆さまとご家族の皆さま，並びに，配布にご協力い ただいた特別支援学校・児童発達支援センター・親の会他各関係機 関の皆さまに謝意を表します。

\section{注}

注1) 医療的ケアとは，疢の吸引や経管栄養など看護師や保護者等が日常的・ 継続的に行っている行為を指す。

注2）「障害者の日常生活及び社会生活を総合的に支援するための法律及び児 童福祉法の一部を改正する法律（2018年 4 月 1 日施行）」の公布をう け，厚生労働省社会・援護局上り通達（障発0603第 1 号 2016 年 6 月 3 日）が出され，障害児支援のニーズの多様化へのきめ細かな対応やサー ビスの質の確保・向上に向けた環境整備等の準備がされ始めている.

注3) 学校教育では「排泄指導」といら用語を用いているが, 中村らは「排泄 の育ちの学びなおしを通して人間の育ち全般を学ぶための「排泄教育」 としている.

注4)アンケートは基本的に無記名としたが，アンケートの結果送付希望者又 は，在宅訪問調查承諾者に限り，任意で住所氏名の記載を依頼した。

注5) 本稿における排泄障害とは, 医学的な膀胱直腸障害のほか, 失禁や失 敗，さらに，夜尿を含み，日常生活上で問題となる状態を指寸。

注6)知的障害もしくは発達障害又は，その両方を併せ持つものとする。

注7) 本項では, 身体障害 (肢体不自由・視覚障害・聴覚障害・内部障害のい ずれかもしくは複数) と知的障害 (発達障害・自閉症スペクトラム障害ほ かのいずれかもしくは複数）の両方を併せ持つものを〈重複〉とする.

注8)図表作成では，最も人数の多い〈重複〉を最初に記述する。

注9）〈重複〉においては，手帳の所持がなくても，アンケートでの主障害の 記載欄において身体障害と知的障害もしくは発達障害またはその両方の 併記があれば〈重複〉とした，また，身体障害者手帳及び療育手帳の両 方所持はあるが，主障害の記載がない場合も〈重複〉として扱った。

注10)療育手帳の等級「A 1 (最重度)」は, 東京都における等級「 1 度 (最重 度)」とした，同様に，「A $2 」 を 「 2$ 度」, 「B 1 」を「 3 度」, 「B $2 」 を 「 4$ 度」と置き換え, 集計した。

注11)「導尿」とは, 尿道口にカテーテル(細い管)を挿入し, 膀胱にたまっ た尿を排出する.「人工膀胱・肛門」とは, 膀胱や肛門に代わって腹部 に排泄用に作られる代用の膀胱や肛門。排泄物は腹部に取り付けたパウ チ(袋)に排出する.「尿道留置カテーテル」とは, 膀胱内にカテーテル を挿入した状態. カテーテルは蓄尿袋と接続し，尿をためておく．

注12)アンケートには「絵文字・意思伝達装置」を選択肢に記載したが，該 当者はわずか数名 (重複 1 名，身体 2 名)であったため，この回答を類似 項目の「身ぶり・指さし・サイン」内に含めて集計した。

注13）「側わん」とは，春柱が側方へ曲がっている状態。

注14）「移動・移乗用リフト」「ストレッチャー」の選択肢を設けたが，該当 者がいなかったため，表から削除した。

注15)カテゴリカル主成分分析にはPASW Statisticを用いた.

注16) 確認のため 3 障害でのカテゴリカル主成分分析を行ったが，〈知的・ 発達〉を〈重複〉〈身体〉と同等に分析しても身体障害と知的障害の 2 極に分類することしかできなかった. そのため〈知的・発達〉を除外し た. さらに, 〈知的・発達〉のみでカテゴリカル主成分分析を行い〈重 複〉及び〈身体〉と同様に 4 分類 (年齢高く最重度, 年齢低く最重度, 年 齢高く中軽度, 年齢低く中軽度）に分け，排泄環境に関する分析を行っ 
たが顕著な相違がみられなかったため, 本項では細分類せず〈知的・発 達〉を一分類として分析に追加した。

注17)説明変数には 12 項目以外に「性別」おむつ使用の有無」「光に敏感」ほか 感覚・姿勢等, 移動方法の項目を投入したが, 「性別」など一つの変 量が極端に大きな成分負荷を示し、他の変量間の成分負荷の違いが見 いだせなくなったもの，もしくは「光に敏感」など極端に分散が少な いため, 分析が収束しなかったものなどがあった。こうした項目を除 外した結果である.

注18)カテゴリカルポイントの結合プロット間の空間距離が長いほうが関連 性について, より強く説明している.

注19）アンケートでは「外出先」とは「通園・通学先」以外で一週間のう ち, 最も頻度が高い外出場所を想定」して回答を依頼した. 外出先

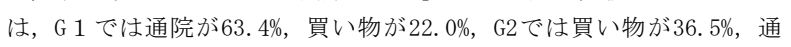
院が $35.1 \%$, G 3 では買い物が $37.4 \%$, 通院が $35.4 \%$, G4 では買い物が

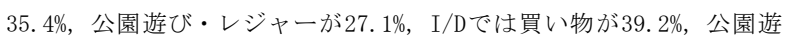
び・レジャーが29.4\%である.

注20) カイ二乗検定の結果, G 1 の通園・通学先の排尿・排便及び外出先の排 尿, G 2 の通園・通学先の排尿・排便（自宅の排便は検定不能）, G 4 の 外出先の排尿・排便は $\mathrm{p}>0.05$ であるが，他は全て $\mathrm{p} \leqq 0.05 \%$ ※゙ある.

注21) 設備 ・ 用具類のうち, 便器等の「差し込み便器」及び移乗・移動用具 等の「リフト類」は選択肢を設けたが該当者がいなかったため, 表か ら削除した。なお，障害に配慮した排泄関連の設備・用具について例 を下記に記す。

・長型便器は, 主に重度障害児者が使用し, 便座と便器が通常より長い 便器を指す(イラスト1 : Long toilet bowl).

・姿勢保持用前方支持類は, 便器に座った状態で前方から抱え込むよう に座位を安定させるための台や机などの用具類を指す(イラスト 2 : Tools to support front to maintain posture).

・姿勢保持用固定ベルトは, 便器に座った状態で背部もしくは側方から 胸部または腰部を固定するベルト類を指す(イラスト 3 :Belts to fix the body to maintain posture).

・姿勢保持機能付き便座は, 座面の形状が慰部に合わせて作られ便器の 上にのせて使用する便座を指す(イラスト4 :Toilets with tools to maintain posture) .

・トイレ用車いす(シャワー用車いす) は, 座面に穴が開いてあり便器に 重ねて使用する車いすを指す（イラスト5：Wheelchair for toilet）.

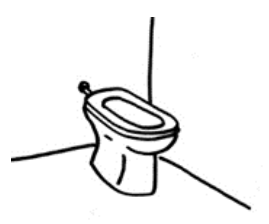

イラスト 1 長型便器

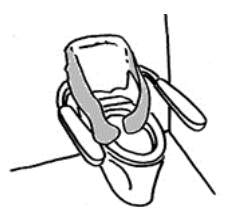

イラスト 3

姿勢保持用固定ベルト
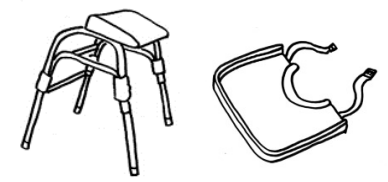

イラスト 2 姿勢保持用前方支持 例

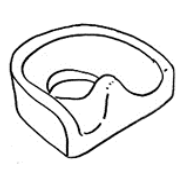

イラスト 4

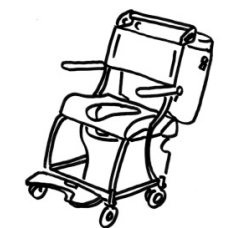

イラスト 5 トイレ用車いす
注22）自己導尿用のカテーテルや人工膀胱・肛門用のパウチなど医療的ケア に使用する用具類を指す.

注23)介助者とは, 自宅では保護者とみなす.

注24）「異食」とは通常食べ物とされないものを口に入れてしまう行為, 「ろう便」とは便をいじる，壁や床にこすりつけるなどの行為を指す．
注25）I/Dは男児の割合が多く，かつ，主たる介助者が母親の組み合わせであ るため, 異性介助が多い。

注26)二分脊椎症とは, 春髄が脊椎の外に出て癒着や損傷しているために起 こるさまざまな神経障害. 個別差があるが，学齢期になると排泄障害に 対し自己導尿等セルフケアの訓練が必要になる.

注27) 2014 年 2 月〜 2015年 4 月, 障害のある览 (者)一個別形式 8 名, 座談会 形式 6 名ヒアリング調查を実施.さらに，2016年 7 月〜 2017年 3 月, 自 宅訪問調査を25名に実施.

\section{参考文献}

1) MEXT Ministry of Elementary and Secondary Education:FY2015. Survey results on medical care of special support schools(NO. 3), p3, 2016.4 (in Japanese)

文部科学省初等中等教育局特別支援教育課：平成27年度特別支援学校等 の医療的ケアに関する調査結果について(別紙3), p3, 2016.4

2) Yamazaki, M. et al. : Survey on children who need home medical care, FY2015. Support status of disabled people survey research project report, p. 42, 2016. 3 (in Japanese)

山崎学他：在宅医療ケアが必要な子どもに関する調査, 平成 27 年度障害 者支援状況等調査研究事業報告書, p. 42, 2016. 3

3) Nishimura, K. : Continence care Book, GAKKEN, p10, 2011.5(in Japanese) 西村かおる：排泄ケアブック, 学研, p10,2011.5

4) Egusa, Y. et al. : Medical and Education manual for Sever motor and intellectual disabilies, Vol. 2, ISHIYAKU Syuppan, pp. 133-136, 2014. 1 (in Japanese)

江草安彦監修：重症心身障害療育マニュアル第2版, 医歯薬出版株式会社, pp133-136, 2014. 1

5) Nakamura, K. et al. : Excretion education to raise children's mind and body of disabled children, OCYANOMIZU Syobou, pp. 10-18. 2015.7 (in Japanese)

中村敬子他：障害の重い子どものこころと体を育てる排泄教育, 御茶の水書 房, pp10-18, 2015. 7

6) Nomura, K. : Renovation of homes considering excretion, Biomechanism Society, Vol. 32, N0. 4, pp. 208-214, 2008.7 (in Japanese)

野村歡：排泄のための住環境整備, バイオメカニズム学会誌, Vol. 32, No. 4, pp. 208-214, 2008. 7

7) Noguchi, Y.ed al. : Study on improvement of living environment for nurturing children with disabilities and supporting independence, FY2007, MIZUH0 Welfare Grant Foundation Social Welfare Promotion Project Research Report, pp. 34-35, 2008. 11 (in Japanese) 野口祐子他：障害児の育成と自立支援のための住環境整備に関する研究, 平成19年度みずほ福祉助成財団社会福祉助成事業研究報告, pp $34^{-} 35$, 2008. 11

8) Ueda, M. et al. : Renovation of homes for children with intellectual disabilities -A Study of Attachment and Environment-, Rehabilitation Engineering Society of JAPAN, VOL. 17, pp589-592, 2002.8(in Japanese) 植田瑞昌他：知的障害のある児・者に対する住環境整備について〜こだわ りと環境に関する一考察〜, 第17回リ八工学カンファレンス講演論文集, pp. 589-592, 2002.8

9) Nishimura, A. and Honda, H. : The guide book of the intellectual and developmental disabilities child's house renovation, CYUOUHOUKI Syuppan, pp49-52, 2016.8 (in Japanese)

西村顕・本田秀夫：知的障害・発達障害のある子どもの住まいの工夫ガイ ドブック危ない! 困った! 存安全・安心に, 中央法規出版, pp. 49-52, 2016. 8 


\author{
Mizuyo UEDA ${ }^{* 1}$ and Takeshi YATOGO ${ }^{* 2}$ \\ ${ }^{* 1}$ Grad. Student, Graduate School of Sience and Technology, Nihon University, M.Eng. \\ ${ }^{* 2}$ Prof., Dept. of Town Planning and Design, CST, Nihon University, Dr.Eng.
}

Independent excretion requires disabled children to acquire communication ability and the ability to maintain posture throughout the process of growth. These efforts require a combination of medical care, rehabilitation and education.

However, under the current circumstances, teaching and training for excretion are provided at hospitals, rehabilitation facilities or schools when they are not given under home conditions. Further, the need for the development of changing excretion environments along with the growth of disabled children is not referred to.

No studies have been found that address these issues as well as appropriate excretion environments based on the stages of growth or development of disabled children from the perspective of architectural planning studies.

Consequently, the objective of our studies is to highlight the current situations and environments of excretion among disabled children and the actual conditions of the development of excretion environments based on the stages of growth or development of disabled children (physical/intellectual ability).

We conducted a survey using a questionnaire and obtained responses from 729 disabled children.

We classified the disabled children based on the physical or excretion conditions into groups that share similar difficulties in terms of excretion environments and analyzed them group by group. Our survey revealed the following:

1. Some disabled children use diapers in spite of no excretion disability.

If children have difficulties going to the toilet owing to reason of physical functions, housing environments need to be developed from the perspective of caregivers who assist disabled children with moving.

2 . The development of excretion environments would enable disabled children to excrete or change diapers at the toilet.

Even though disabled children use diapers at their houses, they would be able to excrete at the toilet using assistance tools or toilet bowls of various shapes at rehabilitation facilities or schools. The development of excretion environments at houses which allow disabled children to excrete without help is needed.

3. Few houses have sufficient excretion environments.

Information on how to develop environments at houses or subsidy housing is lacking.

4. Excretion environments at public toilets away from home are highly unsuitable.

That they have no table for adults to change children's diapers suggests they do not assume use by disabled children.

5. Children with severe intellectual disability such as sound hypersensitivity, allotriophagy or coprophilia have different issues from physically disabled children with respect to the development of excretion environments. 